\title{
The Kidney in Antiphospholipid Syndrome
}

\author{
Alexandru Caraba ${ }^{1}$, Viorica Crişan ${ }^{1}$, Andreea Munteanu' ${ }^{1}$, \\ Corina Şerban ${ }^{1}$, Diana Nicoară ${ }^{2}$ and Ioan Romoşan ${ }^{1}$ \\ 1University of Medicine and Pharmacy „Victor Babeş”, Timişoara \\ 2Selfmed Clinique, Timişoara \\ Romania
}

\section{Introduction}

Graham Hughes described in 1983 a syndrome, characterized by recurrent arterial and venous thrombosis, pregnancy morbidity, thrombocytopenia, and the presence of antiphospholipid antibodies (aPL), which was named antiphospholipid syndrome [Hughes, 1983]. Many other features of this syndrome were identified during the time. In present, antiphospholipid syndrome is considered a systemic form of autoantibody-induced thrombophilia, which involves many organs [Wilson et al., 1999].

Antiphospholipid antibodies (aPL) are: lupus anticoagulant (LA), anticardiolipin antibodies $(\mathrm{aCL})$, and anti- $\beta_{2}$-glycoprotein I antibodies [Cervera et al., 2002]. Classification criteria for the antiphospholipid syndrome had been updated by Miyakis et al. in 2006 [Miyakis et al., 2006].

Antiphospholipid syndrome was first described in patients with systemic lupus erythematosus. Now, it is known that this syndrome may be associated with another disorder (autoimmune diseases, malignancies, infections or drugs), or, may be appear alone, named as primary antiphospholipid syndrome [Sinico et al., 2010].

This disorder may involve any organ in the body, due to vascular thrombosis. The kidney involvement represents one of the most important features of this syndrome. Renal manifestations reflect the extension of thrombotic process in the kidney vascular bed: main renal arteries, intrarenal arteries and arterioles, glomerular capillaries, renal veins [Tektonidou et al., 2000; Vlachoyiannopoulos et al., 2001]. Besides the thrombotic lesions, glomerulonephritis were described in patients with primary antiphospholipid syndrome, too [Nochy et al., 2002; Fakhouri et al., 2003; Sinico et al., 2010].

Renal involvement appears in $2.7 \%$ of patients with antiphospholipid syndrome [Cervera et al., 2002], but the real incidence is greater. The explanations of this underestimated incidence are represented by the fact that renal biopsy is a high-risk procedure in patients treated with anticoagulants, and, on the other hand, renal manifestations of antiphospholipid syndrome are frequently attributed to other conditions, as essential hypertension, or, lupus nephritis [Tektonidou, 2009]. In catastrophic antiphospholipid syndrome, kidney involvement was reported in $78 \%$ of cases [Uthman, Khamashta, 2006]. Renal manifestations associated with antiphospholipid syndrome are summarized in table 1 [Uthman, Khamashta, 2006]. 


\begin{tabular}{|l|ll|}
\hline \multicolumn{1}{|c|}{ Renal manifestation } & \multicolumn{2}{c|}{ Main clinical and laboratory findings } \\
\hline Renal artery lesions & $\bullet$ & $\begin{array}{l}\text { hypertension } \\
\text { decreased glomerular filtration rate }\end{array}$ \\
\hline Hypertension & $\bullet$ & $\begin{array}{l}\text { hypertension } \\
\text { decreased glomerular filtration rate }\end{array}$ \\
\hline Antiphospholipid syndrome nephropathy & $\bullet$ & $\begin{array}{l}\text { hypertension } \\
\text { proteinuria } \\
\text { hematuria } \\
\text { decreased glomerular filtration rate }\end{array}$ \\
\hline Renal vein thrombosis & $\bullet$ & $\begin{array}{l}\text { proteinuria (even nephrotic syndrome) } \\
\text { hematuria }\end{array}$ \\
\hline End stage renal disease/renal transplant & $\bullet \quad \begin{array}{l}\text { decreased glomerular filtration rate } \\
\text { vascular thrombosis of renal allograft }\end{array}$ \\
\hline
\end{tabular}

Table 1. Renal manifestations in antiphospholipid syndrome

\section{Renal artery lesions}

Renal artery lesions are represented by stenosis or occlusion. Renal artery stenosis, thrombosis and renal infarction were described by many authors [Asherson et al., 1991; Ames et al., 1992; Mandreoli et al., 1992; Godfrey et al., 2000]. The first case of renal artery involvement in antiphospholipid syndrome was reported by Ostuni et al. [Ostuni et al., 1990]. They described the appearance of renal artery thrombosis and hypertension in a young female patient with high titers of aCL and a false positive venereal disease research laboratory test. Then, Asherson et al. reported the case of young man with primary antiphospholipid syndrome, who suddenly developed severe hypertension due to right renal artery stenosis [Asherson et al., 1991]. Another patient described by Ames and collaborators presented hypertension and oliguria, bilateral renal artery occlusions on renal arteriography and high titers of circulating aPL [Ames et al., 1992]. Sangle et al., using magnetic resonance angiography, identified that $26 \%$ of the aPL-positive patients with severe, poorly controlled arterial hypertension had renal artery stenosis, compared with $8 \%$ in young aPL-negative hypertensive patients [Sangle et al., 2003]. The renal artery stenosis in aPL-positive patients has two patterns. In the first, most common, the stenosis is smooth, well-delineated, often non-critical, localized distal to the renal artery ostium. Another pattern, less common, is localized proximally, occasionally involving the aorta [Uthman, Khamashta, 2006; Tektonidou, 2009]. The common features of renal artery stenosis are represented by: renovascular hypertension and decrease of glomerular filtration rate [Mandreoli, Zuccheli, 1993]. Reno-vascular hypertension in patients with antiphospholipid syndrome and inadequate anticoagulation has a progressive evolution, leading to the renal impairment function [Sangle et al., 2005]. Based on the thrombotic basis of these renal lesions, Sangle et al. recommended that all the hypertensive patients with aPL-related renal artery stenosis need to be treated with anticoagulant drugs, irrespective of the presence of previous thrombotic events [Sangle et al., 2005]. Renal artery thrombosis determines the occurrence of severe hypertension or a worsening of a 
previously arterial hypertension. In some cases, these patients present pain in lumbar area, hematuria, or decreased of renal function. This renal artery disorder is caused by in situ thrombosis or embolism from heart valve. Other factors involved in the appearance of thrombosis are represented by increased levels of endothelin and accelerated atherosclerosis. The complete occlusion of renal arteries leads to renal infarcts. They may be symptomatic (uni-, bilateral lumbar pain, hypertension, hematuria, oliguria if the lesions are bilateral), or may have a subclinical evolution. In the latter case, the old infarcts may be discovered by imagistic methods [Sonpal et al., 1993].

Imagistic methods such as renal ultrasonography (including main renal artery Doppler ultrasonography), computed tomography, renal scintigraphy, renal angiography, and gadolinium enhanced magnetic resonance angiography contribute to the diagnosis and severity assessment of the renal arteries lesions [Mandreoli, Zuccheli, 1993; Sangle et al., 2003].

The treatment consists in antihypertensive, anticoagulants and antiplatelets drugs. Because the high values of blood pressure have a negative impact on renal function, it is reasonable to diminish these values, without worsening the renal function [Asherson et al., 1991; Godfrey T et al., 2000; Tektonidou, 2009]. Although the renal arteries stenoses are often non-critical, it is recommendable to avoid the use of angiotensin-converting enzyme inhibitors and angiotensin receptor blockers in hypertension therapy of these patients [D'Cruz, 2009]. But other authors reported a good control of high blood pressure with angiotensin-converting enzyme inhibitors, angiotensin receptor blockers and calcium channel blockers, without worsening the renal function [Godfrey et al., 2000]. Poststenotic reduction of renal perfusion pressure stimulates the appearance of high levels of angiotensin II, resulting vasoconstriction of the efferent arteriole, which preserves the glomerular capillary filtration pressure. Angiotensin-converting enzyme inhibitors and angiotensin receptor blockers inhibit this compensatory mechanism, and results a reduction of glomerular filtration rate. But the reduction of the glomerular filtration rate is not specific to angiotensin-converting enzyme inhibitors or angiotensin receptor blockers. The reduction of high blood pressure may impair the autoregulation of intrarenal circulation, and then the renal function declines, irrespective of antihypertensive agents. That is why is very important to closely check the renal function after the initiation of antihypertensive therapy [Mimran, 1992]. Remondino et al. demonstrated that the oral anticoagulation may contribute to the recanalization after bilateral renal artery thrombosis with the subsequent normalizing the high blood pressure [Remondino et al., 2000]. The beneficial role of oral anticoagulant therapy (INR of 3.0 to 4.5) in control of arterial hypertension and improve of the renal function was demonstrated by Sangle et al. A value of INR $<3.0$ is associated with poorly controlled blood pressure, and deterioration of glomerular filtration rate [Sangle et al., 2005]. Other therapeutic methods are: thrombolysis, transluminal balloon angioplasty with or without stenting, surgical interventions [Rysana et al., 1998; Sangle et al., 2005; Tektonidou, 2009].

\section{Arterial hypertension}

Hypertension is common in patients with antiphospholipid syndrome. Hughes described in 1983 the features of arterial hypertension in these patients. He sustained that hypertension in patients with antiphospholipid syndrome often fluctuates, apparently correlating with 
the severity of the livedo, inferring the relationship between thrombotic renal lesions and high blood pressure [Hughes, 1984].

The etiology of hypertension in antiphospholipid syndrome is represented by the stenosis or occlusion of renal artery, or, by the intrarenal vascular lesions. Cacoub et al. studied the kidney lesions in a group of 5 patients with antiphospholipid syndrome and malignant hypertension, in the absence of lupus nephritis. These lesions were represented by ischemic glomeruli without proliferation, focal intimal fibrosis, and thrombosis [Cacoub et al., 1992]. Another study performed by Kincaid-Smith et al., revealed fibrin thrombi in glomeruli and in intrarenal arterioles [Kincaid-Smith et al., 1988]. Nochy et al. reported the presence of high blood pressure in $93 \%$ of the 16 patients with primary antiphospholipid syndrome. In some cases, hypertension represented the unique sign of renal involvement in this syndrome. In this study, the authors revealed that the causes of hypertension are represented by intrarenal vascular lesions: arteriosclerosis, fibrous intimal hyperplasia, arterial and arteriolar fibrous, fibrocellular occlusions and thrombotic microangiopathy [Nochy et al., 1999]. In 25 patients with severe essential hypertension, Rollino et al. identified aPL in $8 \%$ of them, a frequency higher than in control population [Rollino et al., 2004]. High levels of anti- $\beta_{2}$-glycoprotein I antibodies were identified by Frostegard et al. in 73 borderline hypertensive patients [Frostegard et al., 1998].

Hypertensive aPL-positive patients had to be extensively investigated: glomerular rate filtration, urinary sediment, proteinuria, renal ultrasonography (including Doppler of renal arteries, veins, and intrarenal vessels) (fig. 1), renal angiography [Tektonidou, 2009].

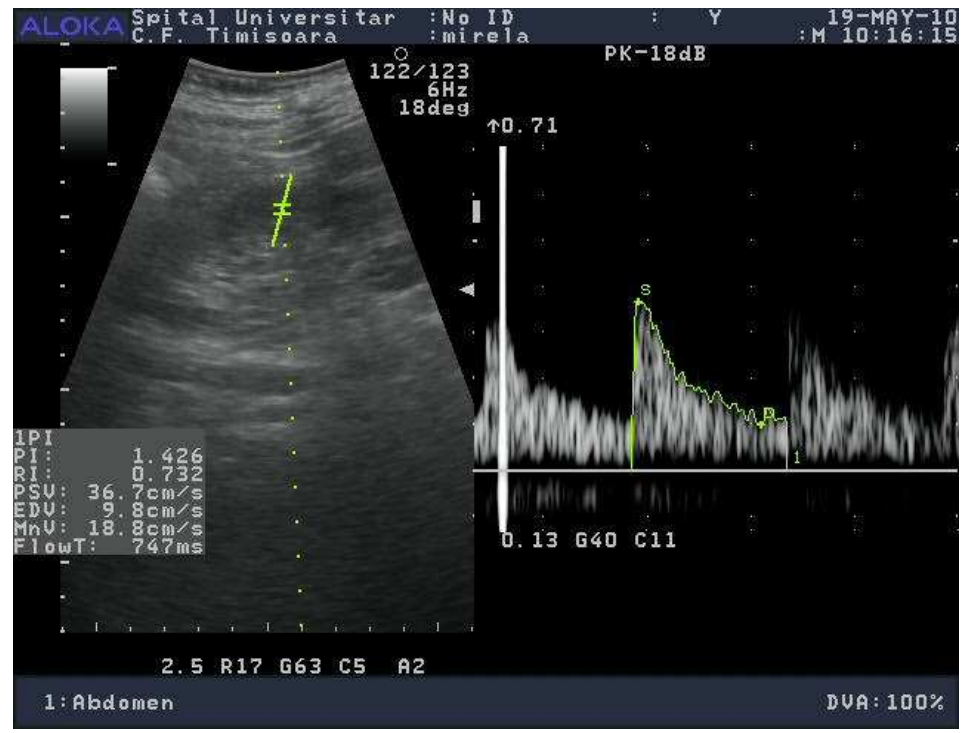

Fig. 1. Increased resistive index (RI) of interlobar renal arteries in hypertensive patient with antiphospholipid syndrome

The objective of the treatment is to obtain reduced blood pressure values in order to preserve the renal function. It is achieved by an association between antihypertensive drugs and anticoagulants [Nochy et al., 2002; Tektonidou, 2009, Sinico et al., 2010]. 


\section{Antiphospholipid syndrome nephropathy}

The intrarenal vascular lesions associated with antiphospholipid syndrome define antiphospholipid syndrome nephropathy. These lesions are represented by: thrombotic microangiopathy, arteriosclerosis, fibrous intimal hyperplasia of arterioles and interlobular arteries, organized thrombi in arteries and arterioles with or without recanalization, fibrous arterial and arteriolar occlusions, focal cortical atrophy [Nochy et al., 1999]. Nochy et al. and Tektonidou et al. revealed that the characteristic features of antiphospholipid syndrome nephropathy are: arterial hypertension, acute or chronic renal failure, proteinuria and microscopic hematuria [Nochy et al., 1999; Tektonidou et al., 2008; Tektonidou, 2009].

Systemic hypertension was identified in $93 \%$ of studied patients by Nochy et al. The severity of hypertension varied from mild to severe, even malignant. Malignant hypertension was described in only one patient, who developed acute renal failure associated with microangiopathic hemolytic anemia, requiring dialysis and progressing to end stage renal disease [Nochy et al., 1999]. It is considered that hypertension represents the most common feature of antiphospholipid syndrome nephropathy. The intrarenal vascular lesions generate systemic hypertension, which may worsen these lesions. Appearance of hypertension in a patient diagnosed with primary antiphospholipid syndrome may reveal the development of nephropathy associated with this disorder. Therefore, the patient with antiphospholipid syndrome who develops hypertension must be extensively investigated, including renal biopsy, irrespective of the presence of proteinuria, hematuria or decreased glomerular rate filtration [Nochy et al., 1999; Tektonidou, 2009; Sinico et al., 2010].

In his study, Nochy identified renal insufficiency in $87 \%$ of patients. It was mild in the most patients (mean value of serum creatinine $1.64 \mathrm{mg} / \mathrm{dl}$ ), being associated with proteinuria and hematuria. End stage renal disease appeared only in one patient [Nochy et al., 1999]. Usually, proteinuria is mild ( $<1 \mathrm{~g} / 24$ hours). In $25 \%$ of patients, it becomes in nephrotic range. Renal lesions in antiphospholipid syndrome nephropathy were described by many authors [Nochy et al., 1999; Griffiths et al., 2000; Tektonidou, 2009, Gigante et al., 2009].

Thrombotic microangiopathy represents the most characteristic lesion in this nephropathy [Amigo et al., 1992; Griffiths et al., 2000]. It is defined by the presence of fibrin thrombi in glomerular capillaries and in intrarenal vessels, without inflammatory cells or immune deposits. The most frequently affected vessels are: preglomerular arterioles, small interlobular arteries, glomerular capillaries. Complete noninflammatory vascular occlusions by intraluminally, subendothelial, and medial accumulation of fragmented erythrocytes, leucocytes and eosinophilic fibrinoid material may be observed. Old lesions are associated with recanalization thrombi. Immunofluorescence shows that the fibrin is the main constituent of these thrombi. Vasculitis was absent in many performed studies [Nochy et al., 1999; Gigante et al., 2009]. Arteriosclerosis lesions consist of fibrous intimal thickening and reduction of arcuate and interlobular arteries lumen. Arteriolar hyalinosis and arteriolosclerosis are identified, too [Gigante et al., 2009]. Fibrous intimal hyperplasia is characterized by intense myofibroblastic intimal cellular proliferation, which determines thickening of intima and tortuosity of interlobular arteries and their branches. The intima seems to be much more cellular than it observed in aging arteriosclerosis. Media may be atrophic and fibrous, or hypertrophic (hypertrophic myocites). Reduced lumen is caused by fibrous thickening of intima or recanalization after thrombosis. The organized thrombi may 
be seen. Small interstitial arteries present fibrocellular and fibrous occlusions [Nochy et al., 1999; Gigante et al., 2009]. Focal cortical atrophy is placed in the superficial zones of the subcapsular cortex, near the renal capsule, which presents a contour depression. It is identified a sharp border between focal cortical atrophy and the normal kidney cortex. This lesion is considered to be very specific for the nephropathy associated with antiphospholipid syndrome. In the regions of focal cortical atrophy, some histological characteristics were described. Glomeruli present two patterns, which may be seen in the same biopsy. Some of them are small and sclerotic, but others are voluminous and pseudocystic. Dense interstitial fibrosis, tubular atrophy, thyroidization and fibrous intimal hyperplasia of the vessels are other histological features. The arterioles are occluded by fibrin thrombi or by fibrous tissue [Gigante et al., 2009]. The main histological features of glomeruli, tubules, interstitium, and intrarenal vessels are presented in table 2.

\begin{tabular}{|c|c|}
\hline Glomeruli & $\begin{array}{l}\text { Light microscopy } \\
\text { - } \quad \text { enlarged } \\
\text { - } \quad \text { normal glomerular cellularity } \\
\text { - } \quad \text { increased number of capillary loops } \\
\text { - } \quad \text { diffusely thickened of capillary walls } \\
\text { - } \quad \text { wrinle contours of glomerular basement membrane (the outer contour is } \\
\text { - } \quad \text { cellular interposition between the glomerular basement membrane and } \\
\text { endothelial cells } \\
\text { Immunofluorescence } \\
\text { - negative } \\
\text { Electron microscopy } \\
\text { - lucent flocculent material between the endothelial cells and glomerular } \\
\quad \text { basement membrane }\end{array}$ \\
\hline Tubules & $\begin{array}{ll} & \text { atrophied } \\
\text { - } & \text { thyroidization }\end{array}$ \\
\hline Interstitium & - fibrosis \\
\hline Intrarenal vessels & $\begin{array}{l}\text { Grade } 1 \\
\text { - } \quad \text { endothelial swelling } \\
\text { - } \quad \text { mild fibrous arterial intimal thickening } \\
\text { and/or } \\
\text { - mild patchy arteriolar hyalinosis } \\
\text { Grade } 2 \\
\text { - moderate fibrous arterial intimal thickening } \\
\text { - } \quad \text { moderate arteriolar hyalinosis } \\
\text { Grade } 3 \\
\text { - severe occlusive intimal thickening } \\
\text { - } \quad \text { thrombosis }\end{array}$ \\
\hline
\end{tabular}

Table 2. The main histological features in antiphospholipid syndrome nephropathy

Griffiths et al. and D'Cruz et al. showed that the redundant, wrinkled segments of glomerular basement membrane and duplicate straighter thin membrane represents pathognomonic findings of antiphospholipid syndrome nephropathy [Griffiths et al., 2000; D'Cruz, 2009]. The 
reports of Asherson, Bucciarelli et al., and Erkan et al. demonstrated that the kidney is one of the most frequently affected organs in catastrophic antiphospholipid syndrome [Asherson, 1992; Erkan et al., 2003; Bucciarelli et al., 2006]. Because of this form of antiphospholipid syndrome is very rare (less than $1 \%$ of antiphospholipid syndrome cases), there are few data about renal histological characteristics. Some cases of catastrophic antiphospholipid syndrome with renal involvement, in which renal biopsies were performed, showed fibrin thrombi in arteries and glomerular capillaries. Chronic vascular lesions were only rare identified [Tektonidou et al., 2008; Tektonidou, 2009]. The efficacy of anticoagulants in the treatment of antiphospholipid syndrome nephropathy wasn't evaluated. Based on the intrarenal thrombotic lesions which characterized this nephropathy, oral anticoagulation seems to be an acceptable therapy, even the long-term effects on renal function are not known, yet [Sinico et al., 2010]. Korkmaz et al. reported that proteinuria was reduced and renal function improved after a combined treatment with immunosuppressive, anticoagulants, calcium channel blockers and angiotensin-converting enzyme inhibitors [Korkmaz et al., 2003].

\section{Renal vein thrombosis}

Asherson et al. described for the first time renal vein thrombosis in two patients with proliferative lupus nephritis and positive LA [Asherson et al., 1993]. D'Cruz suggested that the aPL had an important role in the development of renal vein thrombosis [D'Cruz, 2005].

This lesion is more frequently among the patients with antiphospholipid syndrome and systemic lupus erythematosus than in patients without lupus. Nephrotic syndrome is the main clinical manifestation. Because of this situation, it is indicated that any patient with antiphospholipid syndrome who develops sudden nephrotic range proteinuria should be evaluated by imagistic methods the renal veins (fig. 2).

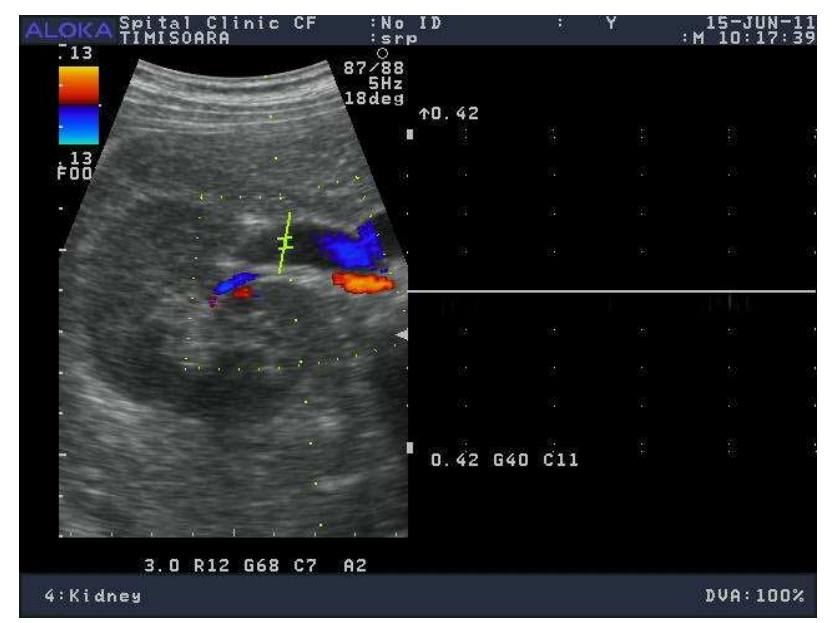

Fig. 2. Renal vein thrombosis (Duplex ultrasonography of the right renal vein)

Renal failure is a consequence of bilateral vein thrombosis. Anticoagulation represents the therapeutic key of this renal complication in antiphospholipid syndrome [Nochy et al., 2002; Tektonidou, 2009]. 


\section{End-stage renal disease/renal transplantation}

In patients undergoing hemodialysis for end-stage renal disease, it was reported a high prevalence of aPL. In a group of 97 patients with end-stage renal disease treated by hemodialysis, Brunet et al. identified LA in 16.5\% of them, and aCL in 15.5\% [Brunet et al., 1995]. No relations between aPL and sex, age, duration of dialysis, hepatitis viruses B, C were identified [Tektonidou, 2009]. Some studies established a relationship between aPL and vascular access thrombosis, especially in patients with LA [Lesar et al., 1999; Haviv, 2000]. Among the patients with renal transplant, it was identified a high incidence of aPL [Tektonidou, 2009]. The risk for vascular thrombosis and renal graft failure was increased in these patients [Andrassy et al., 2004]. Ducloux et al. identified aPL in 28\% of transplant recipients; among them, 18\% developed thrombotic complications [Ducloux et al., 1999]. The risk of thrombotic complications was greater in aPL-positive patients with systemic lupus erythematosus [Moroni et al., 2005]. The role of anticoagulant therapy in aPL-positive renal transplanted patients remains controversial, and prospective studies are necessary in order to establish the best modality for prevention of thrombotic complications [Tektonidou, 2009].

\section{Antiphospholipid antibodies and systemic lupus erythematosus}

Antiphospholipid antibodies are identified in approximately $30-40 \%$ of patients with systemic lupus erythematosus (SLE) [Tektonidou, 2009], but antiphospholipid syndrome appeared in $30 \%$ of cases [Tektonidou et al., 2004]. Hypertension from mild to malignant, hematuria, proteinuria from mild to nephrotic range, acute or chronic renal failure are the main clinical and laboratory findings in patients with SLE and aPL [Kleinknecht et al., 1989]. But all these findings may be the consequence of antiphospholipid syndrome nephropathy without any lesion of lupus nephropathy, or lupus nephropathy alone, or lupus nephropathy associated with antiphospholipid nephropathy. In these conditions, renal biopsy is a mandatory procedure for all the patients with SLE and aPL, who develop renal disease. This procedure provides useful data for prognosis, guiding the therapy [Asherson, Klumb, 2008; Gigante et al., 2009].

The most common renal lesion in patients with SLE and aPL is thrombotic microangiopathy. These patients present mainly arterial hypertension. Acute thrombotic lesions have a progressive evolution to chronic proliferative, obstructive, and fibrotic forms (focal cortical atrophy, fibrous intimal hyperplasia of arterioles, arteriolar occlusions, and sclerotic lesions). Chronic lesions are correlated with raised levels of serum creatinine. The patients who present hypertension and raised levels of serum creatinine at the time of kidney biopsy have an accelerated evolution to end stage renal disease [Tektonidou et al., 2004].

Antiphospholipid syndrome may occur in any class of lupus nephropathy. The studies didn't demonstrate a correlation between the class of lupus nephropathy and the presence of antiphospholipid syndrome. It was no correlation between antiphospholipid syndrome and activity or chronicity index scores, or between aPL titers and anti-DNAds antibodies or serum complement levels [Fofi et al., 2001; Hill, Nochy, 2007].

In patients with any class of lupus nephropathy and aCL, renal biopsies showed a greater degree of sclerosis, crescent formation and glomerular necrosis. Moss and Isenberg demonstrated that in classes III and IV of lupus nephropathy the presence of aPL is 
associated with thrombosis of glomerular capillaries, which may evolve to glomerular sclerosis [Moss, Isenberg, 2001]. Moroni et al. identified a strong association between aPL and class V of lupus nephropathy [Moroni et al., 2004].

Positivity for antinucleosome antibodies at the time of antiphospholipid syndrome diagnosis may predict the subsequent development of SLE [Hill, Nochy, 2007]. Andreoli et al. reported a high frequency of antinucleosome antibodies in patients with antiphospholipid syndrome. Some of these patients developed SLE during the period of follow-up [Andreoli et al., 2008]. Antiphospholipid syndrome patients with membranous nephropathy or proliferative glomerulonephritis represent a group with high risk for developing SLE. Thus, the antiphospholipid syndrome patients with antinucleosome antibodies, membranous nephropathy or proliferative glomerulonephritis need a careful monitoring in order to detect the appearance of SLE [Hill, Nochy, 2007; Andreoli et al., 2008]. On the other hand, Loizou et al. demonstrated that in patients with SLE, the association between aCL, high titers of anti-DNAds and anti- $\mathrm{C}_{1 \mathrm{q}}$ antibodies is very specific for renal involvement [Loizou et al., 2000].These patients benefit by the association between anticoagulants, steroid and immunosuppressive therapy. Immunoadsorption treatment was used in order to reduce the antibodies levels [Hauser et al., 2005].

\section{Glomerulonephritis and antiphospholipid syndrome}

Beside the renal lesions which define the antiphospholipid syndrome nephropathy, in patients with primary antiphospholipid syndrome, kidney biopsies revealed glomerular lesions. Fakhouri et al. identified glomerular lesions in 9 from 29 patients with antiphospholipid syndrome. They were represented by: membranous glomerulonephritis (three cases), pauci-immune crescentic glomerulonephritis (one case), glomerulonephritis with $\mathrm{C}_{3}$ mesangial deposits (two cases), minimal change disease/focal segmental glomerulosclerosis (three cases). The patients from this study presented proteinuria, even in nephrotic range, hematuria, decreased of renal function. They were treated with antihypertensive (six cases), anticoagulants (five cases), steroids (four cases), and antiplatelets drugs (three cases). At last follow-up, renal function was stabilized in seven of these patients [Fakhouri et al., 2003].

Membranous nephropathy was the most described glomerulonephritis among the patients with antiphospholipid syndrome [Dorel et al., 2000; Fakhouri et al., 2003].

Crescentic glomerulonephritis may be present in patients with primary antiphospholipid syndrome. Cisternas et al. and Dede et al. reported two cases of crescentic glomerulonephritis who developed in patients with primary antiphospholipid syndrome [Cisternas et al., 2000, Dede et al., 2008]. Cisternas et al. showed an association between catastrophic antiphospholipid syndrome and crescentic glomerulonephritis with renal failure [Cisternas et al., 2000]. Dede et al. described the case of a young female with pauciimmune glomerulonephritis, $\mathrm{p}$-ANCA positive that had a favourable evolution under the therapy consisted of steroids and cyclophosphamide. After 3 months of follow-up, the patient was in clinical and laboratory remission [Dede et al., 2008].

Abdalla et al. reported a case of membrano-proliferative glomerulonephritis with no evidence of thrombotic microangiopathy or systemic lupus erythematosus. The authors 
sustained the role of immune deposits in pathogenesis of proliferative glomerulonephritis associated with primary antiphospholipid syndrome [Abdalla et al., 2006].

Another type of glomerular lesion was identified by Bhowmik et al. They described a case of focal segmental glomerulosclerosis who had a favourable course under the treatment with aspirin, heparin (during pregnancy), then angiotensin-converting enzyme inhibitors, angiotensin receptor blockers and steroids [Bhowmik et al., 2005].

The therapy of glomerulonephritis associated with antiphospholipid syndrome is based on steroids, immunosuppressive drugs, angiotensin-converting enzyme inhibitors, angiotensin receptor blockers, aspirin or anticoagulants [Dorel et al., 2000; Fakhouri et al., 2003; Bhowmik et al., 2005; Abdalla et al., 2006; Dede et al., 2008].

\section{References}

Abdalla, A.H., Kfoury, H.K., Al-Suleiman, M, Al-Khader AA. (2006). Proliferative glomerulonephritis and primary antiphospholipid syndrome. Saudi Medical Journal, Vol. 27, No. 7, (July, 2006), pp. 1063-1065.

Ames, P.R.; Cianciaruso, B.; Bellizzi, V.; Balletta, M.; Lubrano, E.; Scarpa, R.; Brancaccio, V. (1992). Bilateral renal artery occlusion in a patient with primary antiphospholipid antibody syndrome: thrombosis, vasculitis or both? The journal of rheumatology, vol. 19, Nr.11, (November, 1992), pp. 1802-1806.

Amigo, M.C.; Garcia-Torres, R.; Robles, M.; Bochiccio, T.; Reyes, P.A. (1992). Renal involvement in primary antiphospholipid syndrome, The journal of rheumatology, Vol. 19, (August, 1992), pp. 1181-1185.

Andrassy, J.; Zeier, M.; Andrassy, K. (2004). Do we need screening for thrombophilia prior to kidney transplantation? Nephrology, Dialysis, Transplantation, Vol. 19 (suppl. 4), (July, 2004), pp. 64-68.

Andreoli L, Pregnolato F, Burlingame RW, Allegri F, Rizzini S, Fanelli V, et al. (2008). Antinucleosome antibodies in primary antiphospholipid syndrome: A hint at systemic autoimmunity. Journal of Autoimmunity, Vol. 30, pp. 51-57.

Asherson, R.A. (1992). The catastrophic antiphospholipid syndrome. The journal of rheumatology, Vol. 19, No.4, (April, 1992), pp. 508-512.

Asherson RA, Klumb EM. (2008). Antiphospholipid syndrome nephropathy in different scenarios. The Journal of Rheumatology, Vol. 35, pp. 1909-1911.

Asherson, R.A.; Noble, G.E. Hughes, G.R. (1991). Hypertension, renal artery stenosis and the primary antiphospholipid syndrome. The journal of rheumatology, Vol. 18, No.9, (September, 1991), pp. 1413-1415.

Bhowmik D, Dadhwal V, Dinda AK, Handa R, Dash SC. (2005). Steroid-responsive focal segmental glomerulosclerosis in primary antiphospholipid syndrome with successful pregnancy outcome. Nephrology, Dialysis, Transplant, Vol. 20, pp. 17261728.

Brunet, P.; Aillaud, M.F.; San Marco, M.; et al. (1995). Antiphospholipid in hemodialysis patients: relationship between lupus anticoagulant and thrombosis. Kidney International, Vol. 48, No.3, (September, 1995), pp. 794-800.

Bucciarelli, S.; Espinosa, G.; Cervera, R. et al. (2006). European Forum on Antiphospholipid Antibodies. Mortality in the catastrophic antiphospholipid syndrome: causes of 
death and prognostic factors in a series of 250 patients. Arthritis and rheumatism, Vol. 54, (August, 2006), pp. 2568-2576.

Cacoub, P.; Piette, J.C., Beaufils $\mathrm{H}$ et al. (1992). Malignant hypertension in the antiphospholipid syndrome (APS) without lupus nephritis, Arthritis and rheumatism, Vol. 35, pp. S360.

Cervera, R.; Piette, J.C.; Font, J.; Shoenfeld, Y.; Camps, M.T.; Jacobsen, S. et al. (2002). EuroPhospholipid Project Group: Antiphospholipid syndrome: clinical and immunological manifestations and pattern of disease expression in a cohort of 1000 patients. Arthritis and rheumatism, Vol. 46, No.4, (April, 2002), pp. 1019-1027.

Cisternas M, Gutierrez MA, Rosenberg H, Jara A, Jacobelli S. (2000). Catastrophic antiphospholipid syndrome associated with crescentic glomerulonephritis: a clinicopathologic case. Clinical and Experimental Rheumatology, Vol. 18, No.2, pp. 252-254.

D'Cruz D. (2009). Renal manifestations of the antiphospholipid syndrome. Current Rheumatology Reports, Vol. 11, pp. 52-60.

Dede F, Simsek Y, Odabas AR, Ayli D, Kayatas M. (2008). Pauci-immune glomerulonephritis associated with primary antiphospholipid syndrome. Rheumatology International, Vol. 28, No.5, pp. 499-501.

Dorel M, Daniel L, Liprandi A. (2000). Idiopathic membranous glomerulonephritis associated with primary antiphospholipid syndrome. Nephron, Vol. 86, pp. 366-367.

Ducloux, D.; Pellet, E.; Fournier, V.; Rebibou, J.M.; Bresson-Vautrin, C.; Racadot, E.; et al. (1999), Prevalence and clinical significance of antiphospholipid antibodies in renal transplant recipients. Transplantation, Vol. 67, No.1, (January, 1999), pp. 90-93.

Erkan, D.; Cervera, R.; Asherson, R.A. (2003). Catastrophic antiphospholipid syndrome: where we stand. Arthritis and rheumatism, Vol. 48, No.12, (December, 2003), pp. 3320-3327.

Fakhouri, F.; Noël, L.H.; Zuber, J.; Beaufils, H.; Martinez, F.; Lebon, P.; Papo, T.; et al. (2003). The expanding spectrum of renal diseases associated with antiphospholipid syndrome. American Journal of Kidney Disease, Vol. 41, No.6, (June, 2003), pp. 12051211.

Fofi C, Cuadrado MJ, Godfrey T, Abbs I, Khamashta MA, Hughes GR. (2001). Lack of association between antiphospholipid antibody and WHO classification in lupus nephritis. Clinical and Experimental Rheumatology, Vol. 19, pp. 75-77.

Frostegard, J.; Wli, R.; Gillis-Haegerstrand, C.; Lemne, C.; de Faire, U. (1998). Antibodies to endothelial cells in borderline hypertension. Circulation, Vol. 98, No.11, (September, 1998), pp. 1092-1098.

Gigante, A.; Gasperini, M.L.; Cianci, R.; Barbano, B.; Giannakakis, K.; Di Donato, D.; Fuiano G, Amoroso, A. (2009). Antiphospholipid antibodies and renal involvement. American Journal of Nephrology, Vol. 30, No.5, (August, 2009), pp. 405-412.

Godfrey T, Khamashta MA, Hughes GR. (2000). Antiphospholipid syndrome and renal artery stenosis. QJM: An International Journal of Medicine, Vol. 93, No.2, (February, 2000), pp. 127-129.

Griffiths, M.H.; Papadaki, L.; Neild, G.H. (2000). The renal pathology of primary antiphospholipid syndrome: a distinctive form of endothelial injury. QJM: Monthly Journal of the Association of Physicians, Vol. 93, pp. 457-467. 
Hauser AC, Hauser L, Pabinger-Fasching I, Quehenberger P, Derfler K, Horl WH. (2005). The course of anticardiolipin antibody levels under immunoadsorption therapy. American Journal of Kidney Disease, Vol. 46, No.3, (September, 2005), pp. 446-454.

Haviv,Y.S. (2000). Association of anticardiolipin antibodies with vascular access occlusion in hemodialysis patients: cause or effect. Nephron, Vol. 86, (December, 2000), pp. 447454.

Hill GS, Nochy D. (2007). Antiphospholipid syndrome in systemic lupus erythematosus. Journal of the American Society of Nephrology, Vol. 18, pp. 2461-2464.

Hughes G. (1984). Connective tissue diseases and the skin. The 1983 Posser-White Oration. Clinical and Experimental Dermatology, Vol. 9, No.6, (November, 1984), pp. 535-544.

Hughes GRV. (1983), Thrombosis, abortion, cerebral disease, and the lupus anticoagulant. British Medical Journal (Clin Res Ed), Vol. 287, pp. 1088-1089.

Kincaid-Smith, P.; Fairley KF, Kloss M. (1988). Lupus anticoagulant associated with renal thrombotic microangiopathy and pregnancy-related renal failure. QJM: $A n$ International Journal of Medicine, Vol. 68, No. 258, (October, 1988), pp. 795-815.

Kleinknecht D, Bobrie G, Meyer O, Noel LH, Callard P, Ramdane M. (1989). Recurrent thrombosis and renal vascular disease in patients with a lupus anticoagulant. Nephrology, Dialysis, Transplantation, Vol. 4, pp. 854-858.

Korkmaz C, Kabukcuoglu S, Isiksoy S, Yalcin AU. (2003). Renal involvement in primary antiphospholipid syndrome and its response to immunosuppressive therapy. Lupus, Vol. 12, No.10, pp. 760-765.

Lesar CJ, Merrick HW, Smith MR. (1999). Thrombotic complications resulting from hypercoagulable states in chronic hemodialysis vascular access. Journal of the American College of Surgeons, Vol. 189, No.1, (July, 1999), pp. 73-79.

Loizou S, Samarkos M, Norsworthy PJ, Cazabon JK, Walport MJ, Davies KA. (2000). Significance of anticardiolipin and anti- $\beta_{2}$-glycoprotein I antibodies in lupus nephritis. Rheumatology, Vol. 39, pp. 962-968.

Mandreoli, M.; Zuccala, A.; Zucchelli, P. (1992). Fibromuscular dysplasia of the renal arteries associated with antiphospholipid autoantibodies: two case reports. American Journal of Kidney Disease, Vol. 20, pp. 500-503.

Mandreoli, M.; Zucchelli, P. (1993). Renal vascular disease in patients with primary antiphospholipid antibodies. Nephrology, Dialysis, Transplantation, Vol. 8, No.11, pp. 1277-1280.

Mimran A. (1992). Renal effects of antihypertensive agents in parenchymal disease and renovascular hypertension. Journal of the Cardiovascular Pharmacology, Vol. 19 (Suppl. 6): 45.

Miyakis, S.; Lockshin, M.D.; Atsumi, T.; Branch, D.W.; Brey, R.L.; Cervera, R. et al. (2006). International consensus statement on an update of the classification criteria for definite antiphospholipid syndrome (APS). Journal of Thrombosis and Hemostasis, Vol. 4, No. 2, (February, 2006), 295-306.

Moroni, G.; Tantardini, F.; Galleli, B.; Quaglini, S.; Banfi, G; Poli F et al. (2005). The longterm prognosis of renal transplantation in patients with lupus nephritis. American Journal of Kidney Disease, Vol. 45, No.5, (May, 2005), pp. 901-911.

Moroni G, Ventura D, Riva P, Panzeri P, Quaglini S, Banfi G, et al. (2004). Antiphospholipid antibodies are associated with an increased risk for chronic renal insufficiency in 
patients with lupus nephropathy. American Journal of Kidney Disease, Vol. 43, pp. 2836.

Moss KE, Isenberg DA. (2001). Comparison of renal disease severity and outcome in patients with primary antiphospholipid syndrome, antiphospholipid syndrome secondary to systemic lupus erythematosus (SLE) and SLE alone. Rheumatology (Oxford), Vol.40, pp. 863-867.

Nochy, D.; Daugas, E.; Droz, D.; Beaufils, H.; Grünfeld, J.P.; Piette, J.C. et al. (1999). The intrarenal vascular lesions associated with primary antiphospholipid syndrome. Journal of the American Society of Nephrology, Vol. 10, No. 3, (March, 1999), pp. 50718.

Nochy, D.; Daugas, E.; Hill, G.; Grünfeld JP. (2002). Antiphospholipid syndrome nephropathy. Journal of Nephrology, Vol. 15, No.4, (July-August, 2002), pp. 446-461.

Ostuni PA, Lazzarin P, Pengo V et al. (1990). Renal artery thrombosis and hypertension in a 13 year old girl with antiphospholipid syndrome. Annals of Rheumatic Diseases, Vol. 49, No.3, (March, 1990), pp. 184-187.

Piette, J.C.; Cacoub, P.; Wechsler, B. (1994), Renal manifestations of the antiphospholipid syndrome. Seminars in Arthritis and Rheumatism, Vol. 23, No.6, (June, 1994), pp. 357366.

Remondino, G.I.; Mysler, E.; Pissano, M.N et al. (2000). A reversible bilateral renal artery stenosis in association with antiphospholipid syndrome. Lupus, Vol.9, No.1, pp. 6567.

Rollino, C.; Boero, R.; Elia, F.; Montaruli, B.; Massara, C.; Beltrame, G et al. (2004). Antiphospholipid antibodies and hypertension. Lupus, Vol. 13, No.10, pp. 769-772.

Rysana R, Zabka J, Peregin JH, Tesar V, Merta M, Rychlik I. (1998). Acute renal failure due to bilateral renal artery thrombosis associated with primary antiphospholipid syndrome. Nephrology, Dialysis, Transplantation, Vol. 13, No.10, (October, 1998), pp. 2645-2647.

Sangle, S.R.; D'Cruz, D.P.; Abbs, I.C.; Khamashta, M.A.; Hughes, G.R. (2005). Renal artery stenosis in hypertensive patients with antiphospholipid (Hughes) syndrome: outcome following anticoagulation. Rheumatology (Oxford), Vol. 44, No.3, (March, 2005), pp. 372-377.

Sangle, S.R., D'Cruz, D.P.; Jan, W.; Karim, M.Y.; Khamashta, M.A.; Abbs, I.C.; Hughes, G.R. (2003). Renal artery stenosis in the antiphospholipid (Hughes) syndrome and hypertension. Annals of the Rheumatic Disease, Vol. 62, No.10, (October, 2003), pp. 999-1002.

Sinico, R.A.; Cavazzana, I.; Nuzzo, M.; Vianelli, M.; Napodano, P.; Scaini, P.; Ticani, A. (2010). Renal involvement in primary antiphospholipid syndrome: retrospective analysis of 160 patients. Clinical Journal of the American Society of Nephrology, Vol. 5, No.7, (July, 2010), pp. 1211-1217.

Sonpal, G.M.; Sharma, A.; Miller, A. (1993). Primary antiphospholipid antibody syndrome, renal infarction and hypertension. The Journal of Rheumatology, Vol. 20, No.7, (July, 1993), pp. 1221-1223.

Tektonidou, M.G. (2009). Renal involvement in the antiphospholipid syndrome (APS)-APS nephropathy. Clinical Reviews in Allergy and Immunology, Vol. 36, No.2-3, (June, 2009), pp. 131-140. 
Tektonidou, M.G.; Ioannidis, J.P.A.; Boki, K.A.; Vlachoyiannopoulos, P.G.; Moutsopoulos, H.M. (2000). Prognostic factors and clustering of serious clinical outcomes in antiphospholipid syndrome. QJM: An International Journal of Medicine, Vol. 93, Vol.8, (August, 2000), pp. 523-530.

Tektonidou MG, Sotsiou F, Moutsopoulos HM. (2008). Antiphospholipid syndrome (APS) nephropathy in catastrophic, primary and systemic lupus erythematosus-related APS. The Journal of Rheumatology, Vol. 35, No.10, (October, 2008), pp. 1883-1988.

Tektonidou MG, Sotsiou F, Nakopoulou L, Vlachoyiannopoulos PG, Moutsopoulos HM. (2004). Antiphospholipid syndrome nephropathy in patients with systemic lupus erythematosus and antiphospholipid antibodies. Arthritis and Rheumatism, Vol. 50, No. 8, pp. 2569-2579.

Uthman, I.; Khamashta, M. (2006). Antiphospholipid syndrome and the kidney. Seminars in Arthritis and Rheumatism, Vol. 35, No.6, (June, 2006), pp. 360-367.

Vlachoyiannopoulos, P.G.; Kanellopoulos, P.; Gektonidou, M.; Moutsopoulos, H.M. (2001). Renal involvement in antiphospholipid syndrome. Nephrology, Dialysis, Transplantation, Vol. 16 (suppl. 6), pp. 60-62.

Wilson, W.A.; Gharavi, A.E.; Koike, T. et al. (1999). International consensus statement on preliminary classification criteria for definite antiphospholipid syndrome: report of an international workshop. Arthritis and rheumatism, Vol. 42, No.7, (July, 1999), pp. 1309-1311. 


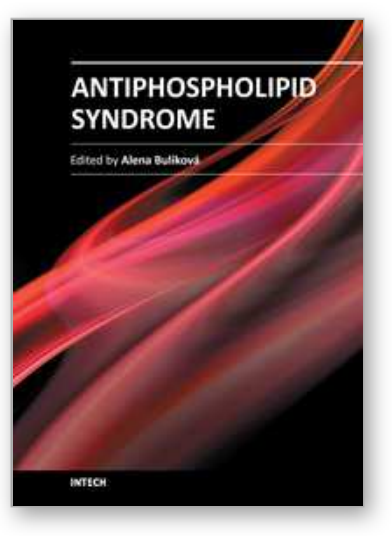

\author{
Antiphospholipid Syndrome \\ Edited by Dr. Alena Bulikova
}

ISBN 978-953-51-0526-8

Hard cover, 232 pages

Publisher InTech

Published online 20, April, 2012

Published in print edition April, 2012

The antiphospholipid syndrome has been described for the first time by Graham Hughes in 1983 as a condition connected with thromboses or foetal losses and antiphospholipid antibodies presence. Form that time there has been a great progress in knowledge, including antiphospholipid antibodies characterisation, their probable and also possible action, clinical manifestations, laboratory detection and treatment possibilities . This book provides a wide spectrum of clinical manifestations through Chapters written by well known researchers and clinicians with a great practical experience in management of diagnostics or treatment of antiphospholipid antibodies' presence.

\title{
How to reference
}

In order to correctly reference this scholarly work, feel free to copy and paste the following:

Alexandru Caraba, Viorica Crissan, Andreea Munteanu, Corina Serban, Diana Nicoaraa and loan Romosan (2012). The Kidney in Antiphospholipid Syndrome, Antiphospholipid Syndrome, Dr. Alena Bulikova (Ed.), ISBN: 978-953-51-0526-8, InTech, Available from: http://www.intechopen.com/books/antiphospholipidsyndrome/antiphospholipid-syndrome-and-the-kidney

\section{INTECH}

open science | open minds

\section{InTech Europe}

University Campus STeP Ri

Slavka Krautzeka 83/A

51000 Rijeka, Croatia

Phone: +385 (51) 770447

Fax: +385 (51) 686166

www.intechopen.com

\section{InTech China}

Unit 405, Office Block, Hotel Equatorial Shanghai

No.65, Yan An Road (West), Shanghai, 200040, China

中国上海市延安西路65号上海国际贵都大饭店办公楼 405 单元

Phone: +86-21-62489820

Fax: $+86-21-62489821$ 
(C) 2012 The Author(s). Licensee IntechOpen. This is an open access article distributed under the terms of the Creative Commons Attribution 3.0 License, which permits unrestricted use, distribution, and reproduction in any medium, provided the original work is properly cited. 